\title{
Renewing knowledge structures for Media Art
}

\author{
Oliver Grau \\ Danube University, Austria \\ Dr.-Karl-Dorrek-Strasse 30, 3500 Krems, \\ oliver.grau@donau-uni.ac.at
}

\begin{abstract}
Over the last thirty years Media Art has evolved into a vivid contemporary factor. Digital Art became 'the art of our time' but has still not 'arrived' in the core cultural institutions of our societies. Thus, we witness the erasure of a significant portion of the cultural memory of our recent history. The development of the field is supported in an increasingly enduring manner by new scientific instruments like online image and text archives, which attempt to document collectively the art and theory production of the last decades. By discussing examples from a variety of projects from the natural sciences and the humanities, this article tries to demonstrate the strategic importance of these collective projects, especially in their growing importance for the humanities.
\end{abstract}

Media Art. Digital Humanities. Archiving. Documentation. Image science

\section{INTRODUCTION}

Although there are well-attended festivals worldwide, well-funded collaborative projects, numerous artist written articles, discussion forums and emerging database documentation projects, media art is still rarely collected by museums, not included or supported within the mainframe of art history and nearly inaccessible for the non northwestern public and their scholars. Thus, we witness the erasure of a significant portion of the cultural memory of our recent history. It is no exaggeration to say we face a total loss of digital contemporary art, and works originating approximately 10 years ago can most likely not be shown anymore. The primary question is: what can we learn from other fields to develop a strategy to solve the problems of Media Art and its research, to answer the challenges Image Science is facing today in the framework of the Digital Humanities? This question opens up a perspective to overcome the typical placement of Media Arts in an academic ghetto.

\section{MEDIA ART'S REVOLUTION?}

Media art is the art form using the technologies that change our societies fundamentally. Globalisation, information society, social networks, and Web 2.0 the list could be far longer - are enabled by digital technologies. Although not all Media Art comments on the social, cultural and political conditions, it is nevertheless the art form with the most comprehensive potential for cultural necessity. We know that media artists today are shaping highly disparate areas, like time-based installation art, telepresence art, genetic and bio art, robotics, Net Art, and space art; experimenting with nanotechnology, artificial or A-life art; creating virtual agents and avatars, mixed realities, and database-supported art. These artworks both represent and reflect the revolutionary development that the image has undergone over the past years (Figure 1).

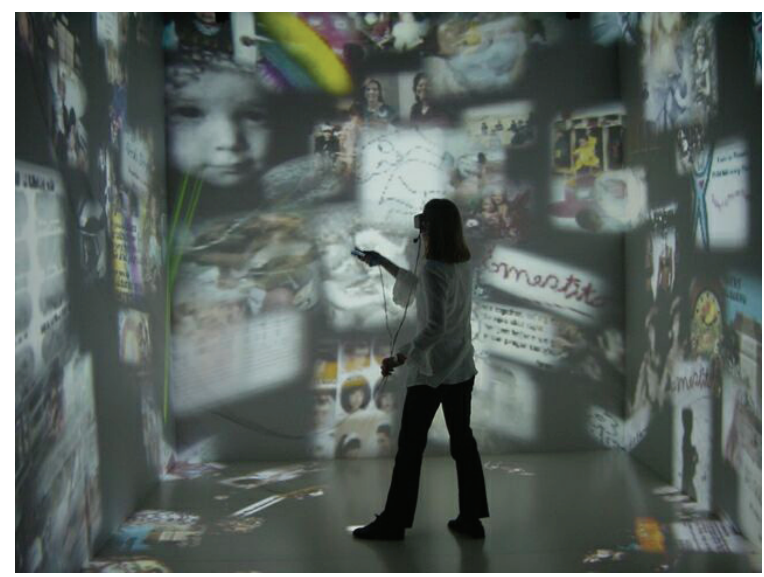

Figure 1: Christa Sommerer and Laurent Mignonneau: The Living Web. Interactive installation by permission of the artists

Contemporary media art installations include: digital stills and video, 3D objects and animation, digital texts and music, sound objects, noises and textures, whereas different meanings may be 
inscribed and combined with each other. Meaning develops by chance, experiment and well-directed strategy. The active spirit, the combining user, becomes the new source of art and meaning if you leave enough degrees of freedom to him to develop to the actual artist. Dynamically he is involved in the navigation, interpretation, transfer, contextualisation or production of image and sound which may come into being by his participation. Memory, thoughts and experiments with accident may respond to a fertile connection. Increasingly the art system transforms to an organism with slices which organise themselves while the user has a chance to experience and produce combinative meaning.

Media Art makes use of the latest image techniques and strategies for aesthetic and reflective means. With Johanna and Florian Dombois' Fidelio, 21st Century, named after Beethoven's Fidelio, for the first time a classical opera was directed as an interactive virtual 3D experience (Dombois \& Dombois, 2001). The protagonists embody music, follow the dramaturgic direction and react to the interventions of the visitors (Figure 2). Artist-scientists, such as Christa Sommerer and Berndt Lintermann, have begun to simulate processes of life; evolution, breeding, and natural selection have become methods for creating artworks (Sommerer \& Mignonneau, 2003). In Murmuring Fields, Monika Fleischmann and Wolfgang Strauss create a virtual space of philosophical thought, where statements by Flusser, Virilio, Minsky, and Weizenbaum are stored. The work creates a new type of a 'Denkraum' (Thinking-Space) - a sphere of thought. Constructed on a database, the interactive installation Ultima Ratio by Daniela Plewe offers a first glimpse of a future system for interactive theatre (Dotzler, 2001; Plewe, 1998; Shikata, 2000).

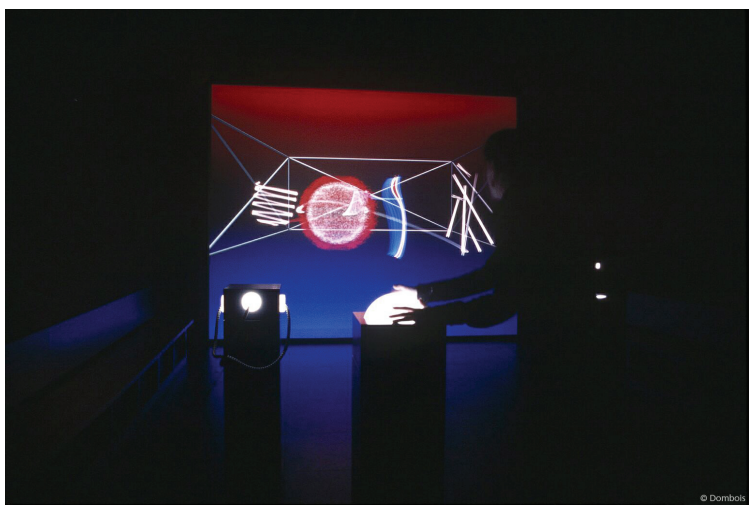

Figure 2: Johanna und Florian Dombois: Fidelio 21st Century. Interactive installation, by permission of the artists

\section{MEDIA ART AND THE HUMANITIES}

It is essential to create an understanding that the present image revolution, which indeed uses new technologies and has also developed a large number of so far unknown visual expressions, cannot be conceived of without our image history. Art History and Media Studies help understand the function of today's image worlds in their importance for building and forming societies. With the history of illusion and immersion, the history of artificial life or the tradition of telepresence, Art History offers sub-histories of the present image revolutions. Art History might be considered as a reservoir in which contemporary processes are embedded, like an anthropologic narration on the one hand, but also the political battleground where the clash of images is analyzed on the other hand. Furthermore, its methods may strengthen our political-aesthetic analysis of the present through image analyses. Not left to last, the development and significance of new media should be illuminated, since the first utopian expressions of a new media often take place in artworks.

The evolution of media art has a long history and now a new technological variety has appeared. However, this art cannot be fully understood without its history. So the Database for Virtual Art, Banff New Media Institute, and Leonardo produced the first international MediaArtHistory conference. Held at The Banff Centre, Refresh! represented and addressed the wide array of 19 disciplines involved in the emerging field of Media Arti. Through the success of Replace (2007) at Berlin's House of World Cultures, (the Department for Image Science hosted the brainstorm conference in Göttweig 2006), Relive was planned for Melbourne 2009, and an established conference series was founded with Rewire 2011 in Liverpool on its way.iii Refresh! was not planned to create a new canon, but to create a space for the many-voiced chorus of the involved approaches. The subtitle HistorlES opened up the thinking space to include approaches from other disciplines beside 'art history'.

Refresh, Replace and Relive were organised via the MediaArtHistory.org platform, which is now developing into a scholarly archive for this multifaceted field, ranging from art history, to media, film, cultural studies, computer science, psychology etc. Meanwhile almost 1,000 peer-reviewed applications have been coordinated on MediaArtHistory.org. ${ }^{\text {iv }}$ With the 19 disciplines represented at Refresh! serving as its base, $\mathrm{MAH}$.org is evolving with future conferences under the guidance of an advisory board, among them: Sean Cubitt, Paul Thomas, Douglas Kahn, Martin Kemp, Timothy Lenoir or Machiko Kusahara. 


\section{IMAGE SCIENCE: FROM THE IMAGE ATLAS TO THE VIRTUAL MUSEUM}

The integration and comparison of a 'new' image form within image history is not a new method; there were different historic forerunners. Inspired by Darwin's work The Expression of the Emotions Aby Warburg began a project of an art-historical psychology of human expression. His famous Mnemosyne image atlas from 1929 tracks image citations of individual poses and forms across media - and most significantly, independent from the level of art niveau or genre. He redefined art history as medial bridge building - for example including many forms of images. Warburg argued that art history could fulfill its responsibility only by including most forms of images. The atlas, which has survived only as 'photographed clusters', is fundamentally an attempt to combine the philosophical with the image-historical approach and Warburg arranged his visual material by thematic areas.

Warburg, who considered himself an image scientist, reflected upon the image propaganda of World War I through examination of the image wars during the reformation. Warburg intended to develop art history into a 'laboratory of the cultural studies of image history', that would widen its field to 'images (...) in the broadest sense'. (Bilder...im weitesten Sinn). ${ }^{v}$

Let us remember too, that Film Studies was started by art historians. An initiative by Alfred Barr and Erwin Panofsky founded the enormous Film Library at the New York MOMA, called by its contemporaries the 'Vatican of Film'. This way film research already in the 1930s possessed a dominant image science approach and cultivated it further. This initiative allowed the large scale comparison of film for the first time. The same spirit concerned with new investments for infrastructures to provide for and analyse the Media Art of our time is needed in the Digital Humanities.

\section{ART HISTORY - VISUAL STUDIES - IMAGE SCIENCE}

With strong representation of art history (Belting, 2007; Bredekamp, 2003), the project of Image Science expands towards an interdisciplinary development that connects neuroscience (Leidloff \& Singer, 2008), psychology ${ }^{\mathrm{vi}}$, philosophy (SachsHombach, 2005), communication studies (Müller, 2003), emotions research (Grau \& Keil, 2005; Hamker, 2003), and other scientific disciplines. ${ }^{\text {vii }}$ Recently, interdisciplinary scientific clusters have been built around the subject of the image that lies increasingly perpendicular to the human, natural and technical sciences, which have succeeded in profiting from the paradigm 'Image' as well as from an increased disposition towards interdisciplinarity. More and more, tendencies appear that require a farewell or at least a new evaluation of the relation Word/Image in favour of the latter. The contemporary critique unfolds in terms like 'Image Immersion' (Grau, 1998 \& 2001); 'Power of the Iconic' (Boehm, 2004); and 'Picture Act'viii. The central thesis is that in every image cognition, the eyes cannot be separated as the sole perception organs, more so it is that the entire body perceives. ${ }^{\text {ix }}$

\subsection{Preconditions}

In contrast to other disciplines concerned with images, ones that not infrequently try to explain images as isolated phenomena springing from themselves, the primary strength of art history is its critical potential to define images in their historical dimension. Exactly because art history emphasises a rigorous historicisation and the practice of a critical power of reflection can it produce its most natural possible contributions to the discussion around images. Scientific work with images is based on three pre-conditions: 1 . definition of the object, 2. building of an image archive, and 3 . familiarity with a large quantity of images. This enables and defines the understanding that images follow a diachronic logic; without this historic base, image science remains superfluous and cannot realise its full potential.

All of those approaches of comparison are based on the insight that images act diachronic, within a historical evolution and never function simply as an act and without reference. This diachronic dynamic of image generations is increasingly interwoven with understanding the images alongside those of their time, the synchronic approach. The dynamic process of change has fueled the interdisciplinary debate about the status of the image, a debate with protagonists such as Mitchell, Belting, Elkins, Stafford and Manovich. ${ }^{\times}$

Image Science, or Bildwissenschaft, now allows us media, from peep-show to panorama, anamorphosis, stereoscope, magic lantern, phantasmagoria, films with odours and colours, cinéorama, IMAX and the virtual image spaces of computers (Grau, 2003).

\section{COLLECTIVE STRATEGIES AND NEW TOOLS FOR THE HUMANITIES}

In the first generation of Digital Humanities ${ }^{x i}$, data was everything. Massive amounts of data were archived, searched and combined with other databases in the 1990s for interoperable searches, yielding a complexity and realisation at a previously inconceivable rate. Yet the amount of material to be 
digitised is so vast that, in real terms, we are only at the tip of the data iceberg. In non-textual fields, such as visual arts, music, performance, media studies, we are 'at the tip of the tip'. Now remember that digital art has still not 'arrived' in our societies; no matter how well-attended digital art festivals are or how many scientific articles the artists have published. Due to the fact that this art depends entirely on digital storage methods, which are in a constant state of change and development, it is severely at risk. Many art works that are not even ten years old can no longer be shown and it is no exaggeration to say that 30 years of art threatens to be lost for the next generations.

During the last decades the natural sciences started to address new research goals through large collective projects; in Astronomy for example the Virtual Observatory compiles centuries worth of celestial observations ${ }^{\text {xii; }}$ global warming is better understood with projects like the Millennium Ecosystem Assignment, at a detail never before calculable, evaluating 24 separate life systems and the global change they are part of. ${ }^{\text {xii }}$ The rapid expansion of computational power has affected biology, and the Human Genome Project has already become legendary. ${ }^{\text {xiv }}$ So far, unknown collective structures give answers to complex problems. For the field of Media Art research and the Digital Humanities in general an appropriate approach is needed to achieve equivalent goals.

Comparable with natural sciences, digital media and new opportunities of networked research catapult the cultural sciences within reach of new and essential research, like appropriate documentation and preservation of media art, or even better, an entire history of visual media and their human cognition by means of thousands of sources. These themes express in regard to image revolution current key questions. In order to push humanities and cultural sciences in their development, it is necessary to use the new technologies globally. Timelines and new methods of visualisation belong to the history of invention of visual techniques, image content and especially their reception in the form of Oral History in popular and high culture, in the western as well as in nonwestern cultures. So we live in an exciting time for Image Science and the Humanities! The credo is: not to give up the established individual research, but to complete it in a new way through collective, net-based working methods which allow us to deal with explosive questions in the field of humanities and cultural sciences.

\section{a. The Database of Virtual Art}

Begun as a counterpart to the systematic analysis of the triad of artist, art work and beholder in digital art under the title Virtual Art, we originated the first documentation project, the Database of Virtual Art
(Figure 3), which celebrated its tenth anniversary last year (Grau, 2000). As a pioneer, supported by the German Research Foundation, it has been documenting in cooperation with renowned media artists, researchers and institutions the last decades of digital installation art as a collective project. We know that today's digital artworks are processual, ephemeral, interactive, multimedial, and fundamentally context dependent. Because of their completely different structure and nature they require a modified, we called it some years ago, an 'expanded concept of documentation'.

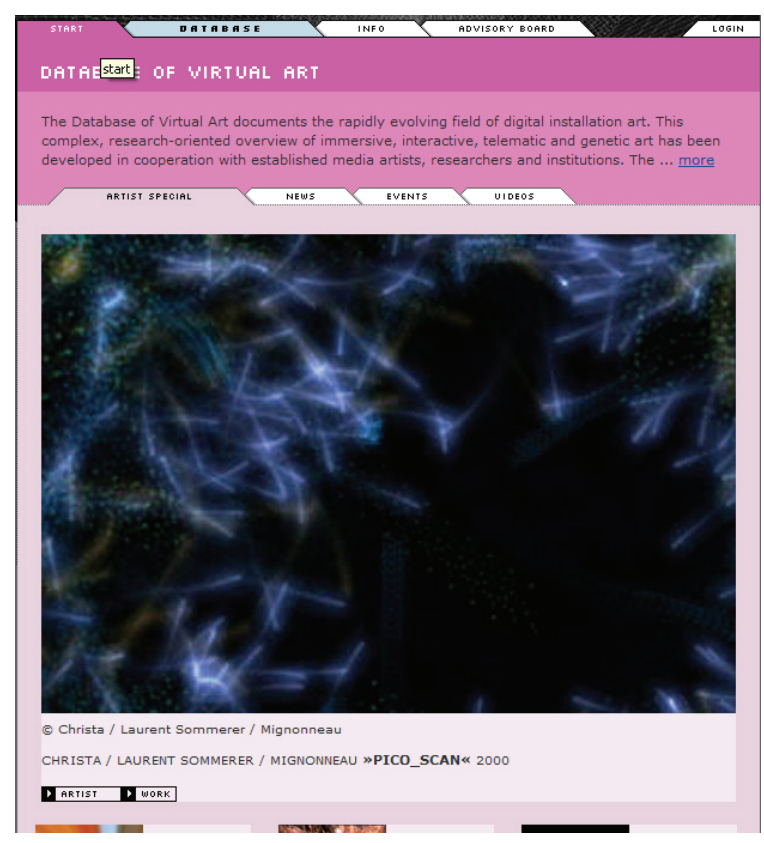

Figure 3: Database of Virtual Art, 1999 - 2009 (Screenshot)

As probably the most complex resource available online, (hundreds of leading artists are represented with several thousand documents and their technical data, more than 2,000 listed articles and a survey of 750 institutions of media art) the database became a platform for information and communication. The Database runs completely on open-source technology and since the artists are members it avoids copyright problems. Beside this group there are theorists and Media Art historians totaling at this point an additional more than 300 contributors - therefore we say the Database of Virtual Art is a/the collective project.

The system allows artists and specialists to upload their information and the DVA relies on its advisory board represented by Christiane Paul, Roy Ascott, Steve Wilson or Jorge La Ferla. Beside that, the policy of whether an artist is qualified to become a member is the number of exhibitions, publications, awards and public presentations; high importance is ascribed also to artistic inventions like innovative interfaces, displays or software. The system offers 
a tool for artists and specialists to upload individually information about works, people, literature, exhibits, technologies, and inventions. ${ }^{\text {xi }}$ In 2000 the DVA started to stream video, documenting the processual nature of interactive works. Over time the interlinked layers of data will also serve as a predecessor for the crucial systematic preservation of this art. Over the last 10 years about 5,000 artists were evaluated, of which 500 fulfilled the criteria to become a member of the DVA. There are other initiatives where artists, often still students, pay money to be represented. The DVA instead follows systematic criteria of quality through public and scholarly acceptance as much as possible.

The long-term aim of the project was not the documentation of a festival, an award or something similar, but from the beginning the focus was on a scientific overview and quality. The members have to be qualified with at least 5 exhibitions or articles on their work, or alternatively they could be suggested by the board. The main challenge existed and exists during the last 15 years in the establishment, maintenance and advancement of the social corpus, consisting of hundreds of living individuals; artists, whose affiliation is not automatically assumed since the DVA is not defined like other projects, who focus on a festival or a collection.

\section{b. 'Bridging the gap: new developments in thesaurus research}

And now together with probably one of the most important unknown art collections, the Göttweig print collection, representing 30,000 prints emphasising Renaissance and Baroque works ${ }^{\text {xvii }}$ and a library of 150,000 volumes going back to the $9^{\text {th }}$ century, like the Sankt Gallen Codex, the Database of Virtual Art strives to achieve the goal of a deeper Media Art historical cross examination. Just as the Media Art History conference series aims to bridge a gap, the combination of the two and other databases hopes to enable further historic references and impulses, in the manner, Siegfried Zielinski calls 'The Deep Time of Media' (Zielinski, 2006). The Göttweig collection also contains proofs of the history of optical image media (Figure 4), intercultural concepts, caricatures, illustrations of landscapes in panoramic illustrations. For the future this will provide resources for a broader analysis of media art.

Keywording is bridge building! The hierarchical Thesaurus of the DVA constitutes a new approach to systematise the field of Digital Art. It was built on art historical thesauri from institutions like Getty, Warburg Institute or festival categorisations and discussions with artists, so that it supports historical comparisons. Out of the Getty Arts \& Architecture
Thesaurus from the subject catalogue of the Warburg Library in London, keywords were selected which also have relevance in media art. On the other side, out of the most common used terms from media festivals like Ars Electronica, DEAF, Transmediale new keywords were selected. Important innovations such as 'interface' or 'genetic art' have been considered as well as keywords that play a role in traditional arts such as 'body' or 'landscape' and thus have a bridge-building function. It was important to limit the number to 350 words so that members of the database can assign use and keyword their works without great study of the index.

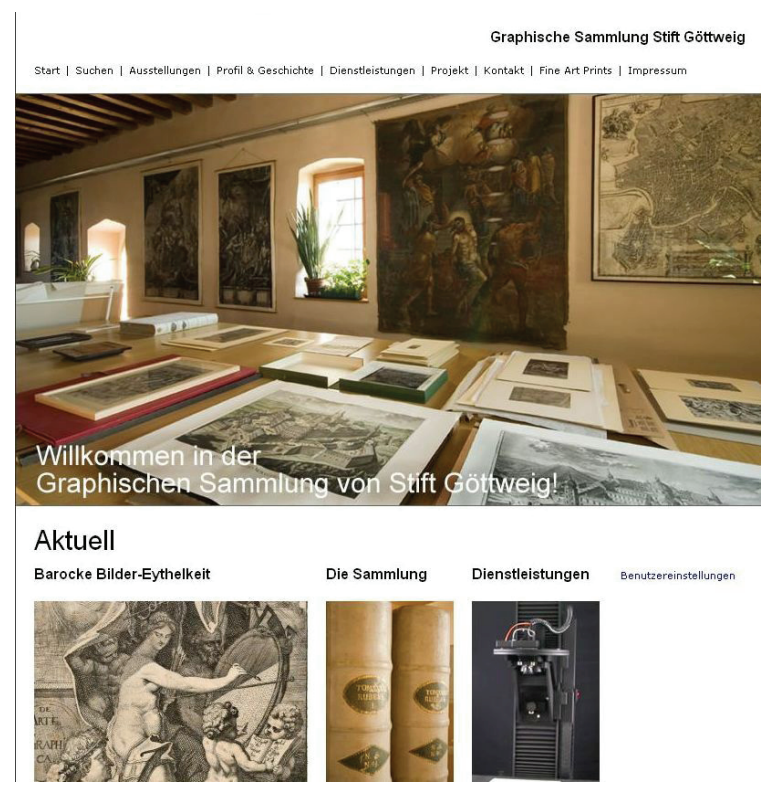

Figure 4: Göttweig Print Collection Online (Screenshot)

The categories led to natural overlapping, so that the hybrid quality of the artworks can be captured through clustering. Important was the thematic usability for the humanities - it was necessary to avoid developing something only new, separated from our cultural history. It was important to compile a thesaurus that connects cultural history with media art and does not isolate them from another. As expected, the material has produced a multitude of fractures and discontinuities, which we make visible in the terminology of the database.

One of the goals for the future is to document the works within a context of complex information and, at the same time, to allow users to find individual details quickly. In addition to statistically quantifiable analyses and technical documentation, Databases should also present personal connections and affiliations and funding information, with the idea to reveal interests and dependence. The term 'database' may be misleading; like Warburg's image atlas which supports key icons that define the extent of 
problems and enables possibilities for comparison, databases should possess an experimental character in order to find thematic clusters within media art. And yet, the tools only hold the data the quality of the analysis continues to rely on thoughtful developments in the Digital Humanities. In addition to searches of themes, Media Art documentation should also admit questions of gender, track the movement of technical staff from lab to lab, technical inventions pertaining to art, the destinations of public and private funds allocated to research, and, through the thematic index, show reminiscences of virtual/immersive art in the forms of its predecessors, for example, the panorama. Media Art documentation becomes a resource that facilitates research on the artists and their work for students and academics, who, it is hoped, will contribute to expanding and updating the information it contains. In this way, documentation changes from a one-way archiving of key data to a proactive process of knowledge transfer.

\section{c. Media Art Education}

Bridging the gap for Media Art means also the use of new telematic forms of education, which enlarge the audience now being able to intervene interactively from other continents, as we practise with the archived Danube Telelectures. The future of Media Art within the Digital Humanities requires the further establishment of new curricula, as we developed with the first international Master of Arts in MediaArtHistories, with faculty members like Erkki Huhtamo, Lev Manovich, Christiane Paul, Gerfried Stocker and Sean Cubitt, which deals also with the practice and expertise in Curation, Collecting, Preserving and Archiving of Media Arts. The necessity for an international program capable of accommodating future scholars coming from diverse backgrounds and all continents was answered by a low-residency model allowing professionals to participate in the advanced program of study parallel to ongoing employment and activities. Students and specialists are brought together for concentrated blocks of time in an intensely creative atmosphere focusing on the histories of media art and its kindred arenas.

It was necessary for the needs of the field to create a program specific to MediaArtHistories with experts that normal universities could not gather all in one institution in order to pave the way towards development of innovative future educational strategies in the field. Giving an overview of the relevant approaches and on the other hand a specialisation via project and masters theses, the Masters of Arts provides an initiation for fresh students and depth for seasoned students into this emergent field. The integration and continuing development of the aforementioned projects, like the Database of Virtual Art, the Göttweig Graphic Collection online and the platform
MediaArtHistory.org with the MediaArtHistoriesArchive synergises with the development of the courses for the program to support curators and archivists in their professional needs. The ultimate goal is to set a standard for other administrators and policy makers so that in the shared space between art history and media studies we can work towards adjoining common methods, histories and research.

\section{THE PROBLEM OF MEDIA ART DOCUMENTATION TODAY - FUTURE NEEDS}

Since the foundation of the Database of Virtual Art a number of online archives for digitisation and documentation arose: Langlois Foundation in Montreal, Netzspannung at the Frauenhofer Institut or MedienKunstNetz at ZKM - all these projects were terminated, their funding expired, or they lost key researchers like V2 in Rotterdam. xviii Even the Boltzmann Institut for Media Art Research in Linz, faced closure due to evaluation. In this way the originated scientific archives which more and more often represent the only remaining image source of the works, not only lose step by step their significance for research and preservation but in the meantime partly disappear from the web. Not only the media art itself but also documentation fads condemn future generations to being unable to get an idea of the past and our time. To put it another way, till now no sustainable strategy exits. What we need is a concentrated and compact expansion of ability. There is/was increasing collaboration with these projects in a variety of areas and in changing coalitions. But let me add some remarks: In the field of documentation projects - real preservation projects do not exist yet $^{\mathrm{xix}}$ - the focus is still directed too much towards particularisation, instead of concentrating forces, what is an essential strategy in most other fields. Many individual projects are definitely innovative but too small and without clear larger scientific strategy and safe financing, which is not their fault. Some projects are already expired and not carried further. So much competence, so much cultural wealth, but so much separatism.

\subsection{A new structure for Media Art research}

Especially the university based research projects and partly also the ones which are linked to museums have developed expertise that needs to be included in cultural circulation, not only in order to pass it on to future generations of scientists and archivists but also to give it a chance to flow into future university education in the fields of art, engineering, and media history. Clearly, the goal must be to develop a policy and strategy for collecting the art of our latest history under the umbrella of a strong, let's say 'Library of Congress like' institution. Ultimately, however, this can only 
be organised by a network of artists, computer and science centres, galleries, technology producers and museums. Those projects which collected culturally important documents in the past and which often expired, were not further supported or even lost their base must be supported and reanimated. They should be organised like a corona around an institution which receives the duty of documentation and may be even the collection of contemporary media art, such an institution could be in the USA, the Library of Congress; in Europe, besides the new European digital libraries database Europeana, it could be the Bibliotheque National, the British Library, the V\&A or in Germany beside the ZKM for example the Deutsche Bibliothek. Interestingly the libraries show increasing interest in archiving multimedia works and their documentation. However, the usually complex cultural and technical knowhow is lacking in order to preserve principal works of the most important media art genres of the last decades. Not only can the international state of Media Art be a hindrance in creating common projects, also the funding infrastructure of media art so far, has normally promoted projects for 2, 3 or more years, neglecting sustainability. A structure which updates, extends and contextualises research whether in historical or contemporary contexts - is required. The funding and support infrastructures which have been built in the end of the last century are not suitable for scientific and cultural tasks in the humanities of the $21^{\text {st }}$ century.

What is needed in the humanities is an institutional support equivalent to that in astronomy, biology or climate research. In order to create enough momentum and adhesion, the main funding organisations, like NSF, NEH, the European Research Council, DFG, Volkswagen Foundation etc. have to support on an international level the necessary research structure for research in Media Art and the Digital Humanities in general needed in the 21st century.

One key issue for the digital humanities would be to identify all the existing databases, also those smaller ones in countries where you do not search first. In astronomy the funding agencies developed and modernised their systems towards sustainability, which is needed as well in the humanities. The virtual observatory infrastructure is funded on an ongoing basis and there is international coordination between a dozen or so countries that produce astronomical data. Considering the current upheavals and innovations in the media sector, where the societal impact and consequences cannot yet be predicted, the problem is acute. Social media competence, which goes beyond mere technical skills, is difficult to acquire if the area of historic media experience is excluded.
Today we watch the exciting developments of the web 2.0 and experiment with new strategies in collective documentation and content management that exceed the work of expert networks. But it has to be kept in perspective that amateurs without adequate education cannot replace the work of professionals who have been educated and established over many years - a process common in other dissemination systems. Nevertheless, amateurs can play a very important role facing the enormous challenge negotiating/traversing through a network of helpful exchanges and efficient guidance. A commitment by the best experts from the field is needed in a long term occupation. Let's recall the enormous and sustaining infrastructure that was developed and established for traditional artistic media painting, sculpture, architecture, even film, photography and their corresponding archives over the course of the century. What is urgently needed is the establishment of an appropriate structure to preserve at least the usual $1-6$ per cent of present media art production, the best works. This important step is still missing for media art from the first two generations. If we compare the world-wide available budget for traditional art forms with the one for digital culture then we understand how inadequate the support for our present digital culture is; so low it is almost statistically immeasurable. The faster this essential modification to our cultural heritage record can be carried out, the smaller the gap in the cultural memory; shedding light on the dark years, which started about 1960 and lasts till now. ${ }^{\times x}$ The hybrid character of media art requires a shift of the paradigm towards an orientation of process and context recording, which includes more and more the capture of the audience experience (Grau, 2003; Muller, 2008).

But even the best documentation and archiving cannot replace preservation, whose research started in a range of international projects such as $D O C A M^{x \times i}$ in Canada, the Variable Media Approach or the Capturing Unstable Media project carried out by V2. We should welcome that further basic means are provided, in order to promote ambitions to perceive media art, even though on a national and international level still by far larger efforts must be undertaken.

Our hope for the future is that we can bring together the expertise of the most important institutions in order to form an up to date overview of the whole field, to provide the necessary information for new preservation programs within the museum field, new university teaching programs for a better training of the next generation of historians, curators, restorers, engineers and others involved in the preservation and new form of open access to media art. Just as research in the natural sciences has long recognised team efforts, 
a similar emphasis on collaborative research should make its way into the thinking of the humanities.

\section{REFERENCES}

Belting, $\mathrm{H}$ (ed.) (2007) Bildfragen: Die Bildwissenschaften im Aufbruch. Fink, Munich.

Boehm, G. (2004) Jenseits der Sprache? Anmerkungen zur Logik der Bilder, In Maar, C. \& Burda, H. (eds.) Iconic Turn. Köln. pp. 28-43, here: p. 30.

Bredekamp, H., Bruhn, M. and Werner, G. (2003-) Bildwelten des Wissens. Kunsthistorisches Jahrbuch für Bildkritik. Akademie Verlag, Berlin.

Dombois, J. and Dombois, F. (2001) op.72. II 1-5, 3D. Beethoven's "Fidelio" in a Virtual Environment. In: Proceedings of the 5th World Multi-Conference on Systematics, Cybernetics and Informatics. Vol. X, Orlando (Florida), July 22-25, 2001, pp. 370373.

Dotzler, B. (2001) Hamlet|Maschine, In Trajekte: Newsletter des Zentrums für Literaturforschung Berlin, no. 3, vol. 2. pp. 13-16.

Fleischmann, M., Strauss, W. and Novak, J. (2000) Murmuring Fields Rehearsals - building up the Mixed Reality Stage. In Proceedings of KES International Conference on Knowledge Engineering Systems, Brighton.

Grau, O. (1998) Into the Belly of the Image, In Leonardo, Journal of the international Society for the Arts, Sciences and Technology. Vol. 32, No. 5, pp. 365-371.

Grau, O. (2000) The Database of Virtual Art. In Leonardo, Vol. 33, No. 4, p. 320.

http://www.virtualart.at

Grau, O. (2001) Virtuelle Kunst In Geschichte und Gegenwart: Visuelle Strategien. Reimer, Berlin.

Grau, O. (2003) Virtual Art: From Illusion to Immersion. MIT-Press, Cambridge/Mass.

Grau, O. and Keil, A. (eds.) (2005) Mediale Emotionen: Zur Lenkung von Gefühlen durch Bild und Sound. Fischer, Frankfurt.

Hamker, A. (2003) Emotion und ästhetische Erfahrung. Waxmann, Münster.

Leidloff, G. and Singer, W. (2008) Neuroscience and Contemporary Art: An Interview. In Hüppauf, B. and Weingart, P. (eds) Science Images and Popular Images of the Sciences. Routledge, London. pp. 227-238.
Muller, L. (2008) Towards an Oral History of New Media Art. Daniel Langlois Foundation, Montreal.

Müller. M. (2003) Grundlagen der visuellen Kommunikation. UVK, Konstanz.

Plewe, D. (1998) Ultima Ratio. Software und Interaktive Installation, In Stocker, G. and Schöpf, C. (eds) Ars Electronica 98: Infowar: Information, Macht, Krieg. Springer Verlag, Vienna/New York.

Sachs-Hombach, K. (ed.) (2005) Bildwissenschaft Suhrkamp, Frankfurt am Main.

Shikata, Y. (2000) Art-criticism-curating as connective process. In Information Design Series: Information Space and Changing Expression, vol. 6. Kyoto University of Art and Design. p. 145.

Sommerer, C. and Mignonneau, L. (2003) Modeling Complexity for Interactive Art Works on the Internet. In Casti, J. and Karlqvist, A. (eds) Art and Complexity: At the Interface. Elsevier, Amsterdam. pp. 85-107.

Zielinski, S. (2006) Deep Time of the Media: Toward an Archaeology of Hearing and Seeing by Technical Means. MIT Press, Cambridge Mass.

' For an overview: http://www.virtualart.at. Recently: Edward Shanken: Art and Electronic Media (London: Phaidon, 2009); Christa Sommerer and Laurent Mignonneau (Eds.): Interface Cultures: Artistic Aspects of Interaction (Bielefeld: Transcript 2008); Victoria Vesna: Database Aesthetics: Art in the Age of Information Overflow (Minneapolis: University of Minnesota Press 2007); Steve Dixon: Digital Performance: A History of New Media in Theater, Dance, Performance Art, and Installation Cambridge (Mass.: MIT Press 2007). Already a classic: Christiane Paul: Digital Art (London: Thames \& Hudson 2003).

ii Some of the conference results can be found in the anthology MediaArtHistories by Oliver Grau (Ed.), (Cambridge Mass.. MIT-Press 2007); recently: Andreas Broeckmann and Gunalan Nadarajan (Eds.): Place Studies in Art, Media, Science and Technology: Historical Investigations on the Sites and the Migration of Knowledge (Weimar: Verlag und Datenbank für Geisteswissenschaften, 2009).

iii See: http://www.mediaarthistory.org 
iv The content development of Refresh! was a highly collective process. It involved three producing partners, a large advisory board, 2 chairs for each session, call and review for papers, a planning meeting in 2004, keynotes, poster session and the development of application content over the time of two and a half years.

The conference brought together colleagues from the following fields: invited speakers (based on selfdescription from bios) HISTORIES: Art History = 20; Media Science $=17$; History of Science $=7$, History of Ideas = 1; History of Technology = 1; ARTISTS/CURATORS: Artists/Research = 25; Curators = 10; SOCIAL SCIENCES:

Communication/Semiotics $=6$;

Aesthetics/Philosophy $=5$, Social History $=2$;

Political Science $=2$; Woman Studies $=2$, Theological Studies = 1; OTHER CULTURAL STUDIES: Film Studies = 3; Literature Studies = 3; Sound Studies $=3$, Theatre Studies $=2$;

Performance Studies = 1; Architecture Studies = 1, Computer Science = 2; Astronomy 1

${ }^{\vee}$ A. Warburg, Heidnisch-antike Weissagung in Wort und Bild zu Luthers Zeiten, in: Zeitschrift für Kirchengeschichte, 40 (1922), pp. 261-262. We know that National Socialism put a sudden end to this work and although its emigrants could create important impulses in the US and England, the image science approach did not return until the 70ies with the Hamburg School. See also: Claudia Wedepohl: Ideengeographie: ein Versuch zu Aby Warburgs 'Wanderstrassen der Kultur', in: Entgrenzte Räume: Kulturelle Transfers um 1900 und in der Gegenwart, eds Helga Mitterbauer and Katharina Scherke, Vienna, 2005.

\footnotetext{
vi See the publications and research projects of
} Helmut Leder.

\section{vii Albeit concentrated on the gravitational field of art history, the courses in Image Science at the Danube University in Göttweig are interdisciplinary aligned. http://www.donau-uni.ac.at/dis.}

viii A first glimpse of his theory of 'picture act' Horst Bredekamp presented during his Gadamer-Lecture series at the University of Heidelberg in 2005. A research project 'Picture Act Research: History, Technique and Theory of the Picture Act' was approved by the German Research Foundation in 2008 and supported with 2.3 Mio Euro.

\footnotetext{
ix Hans Belting emphasised in 2001 that we, as living media, are the 'Location of the Images' and not the apparatuses, see: Hans Belting: BildAnthropologie. Entwürfe für eine Bildwissenschaft (Munich: Fink 2001).
}

\begin{abstract}
x See: David Freedberg: The Power of the Images: Studies in the History and Theory of Response. (Chicago: Univ. of Chicago Press 1989); Jonathan Crary: Techniques of the Observer: On Vision and Modernity in the Nineteenth Century (Cambridge, MA, MIT Press 1990); William J. T. Mitchell: Picture Theory: Essays on Verbal and Visual Representation (Chicago: Univ. Chicago Press 1995); James E1kins: The Domain of Images (Ithaca: Cornell University Press 1999); Lev Manovich: The Language of New Media. Cambridge (MA: MIT Press 2001); Barbara Stafford (with Frances Terpak): Devices of Wonder. From the World in a Box to Images on a Screen (Getty Research Institute, 2001); Thomas Gunning: "ReNewing Old Technologies: Astonishment, Second Nature, and the Uncanny in Technology from the Previous Turn-of -the-Century" in: Rethinking Media Change, The Aesthetics of Transition eds. David Thorburn and Henry Jenkins (Cambridge: MIT Press 2003), pp. 39-59; Erkki Huhtamo: "Elements of Screenology: Toward an Archaeology of the Screen", Iconics, The Japan Society of Image Arts and Sciences, Vol. 7, Tokyo 2004, pp. 31-82.

\section{${ }^{\mathrm{xi}}$ For the discussion and development of the field see the Journal Digital Humanities Quarterly.}

xii The International Virtual Observatory Alliance (IVOA) was formed in June 2002 with a mission to "facilitate the international coordination and collaboration necessary for the development and deployment of the tools, systems and organisational structures necessary to enable the international utilisation of astronomical archives as an integrated and interoperating virtual observatory." The IVOA now comprises 17 international VO projects.

xiii The Millennium Ecosystem Assessment assessed the consequences of ecosystem change for human well-being. From 2001 to 2005, the MA involved the work of more than 1,360 experts worldwide. Their findings provide a state-of-the-art scientific appraisal of the condition and trends in the world's ecosystems and the services they provide, as well as the scientific basis for action to conserve and use them sustainably.

xiv The Human Genome Project was an international scientific research project with a primary goal to determine the sequence of chemical base pairs which make up DNA and to identify and map the approximately 20,000-25,000 genes of the human genome from both a physical and functional standpoint. The mega project started 1990 with the collective work of more than 1,000 
researchers in 40 countries; the plan was to achieve the goal in 2010. A working draft of the genome was released in 2000 and a complete one in 2003. See: IHGSC (2004). 'Finishing the euchromatic sequence of the human genome', in: Nature 431: 931-945. doi:10.1038/nature03001

${ }^{x v}$ Oliver Grau: For an Expanded Concept of Documentation: The Database of Virtual Art, ICHIM, École du Louvre, Paris 2003, Proceedings, pp. 2-15. It was a long development since the classic text by Suzanne Briet: What is Documentation? (Lanham: Scarecrow Press 2006).

xvi The PostGreSQL Database is open Source and the Operation System Linux based.

xvii http://www.gssg.at. The digitisation of the collection is a project developed by the Department of Image Science at Danube University and conducted in cooperation with the Göttweig Monastery. The collection of prints at Göttweig Monastery, which itself was founded in 1083, is based on acquisitions made by various monks since the 15th century. The first report of graphic art kept in the monastery dates back to 1621 , with an archive record that mentions a number of 'tablets of copper engraving' ('Täfelein von Kupferstich'). The actual act of founding the collection is attributed to Abbot Gottfried Bessel whose systematic purchases in Austria and from abroad added remarkably a total of 20,000 pieces to the collection in a very short span of time! Reaching to the present day, the print collection at Göttweig Monastery has grown to be the largest private collection of historical graphic art in Austria with more than 30,000 prints. The Department of Image Science's digitisation centre at the Göttweig Monastery uses technology to scan paintings and prints from the collection (up to 72 million pixels).

xviii Also compare the OASIS (Open Archiving System with Internet Sharing (2004-2007) or the GAMA project (2008-2009), a gateway, a metadatabase, which is not connected with the Europeana. 'The issue of generally accepted machine-readable descriptive languages in these semantic and metadata approaches and the longterm interoperability of databases have led to an emphasis on questions concerning the openness of the sources and the source codes'. Rolf Wolfensberger. On the Couch - Capturing Audience Experience, Master Thesis, Danube University 2009.

${ }^{x i x}$ Although there are a number of promising case studies like: Caitlin Jones: Seeing Double: Emulation in Theory and Practice, The Erl King Case Study.
http://206.180.235.133/sg/emg/library/pdf/jones/JonesEMG2004.pdf

${ }^{x x}$ The loss might be even more radical and total than that of the Panorama, the mass media of the 19th century. Almost 20 Panoramas survived which is much more than 3 per cent of the ever existing $360^{\circ}$ image worlds - we should be glad if at all 3 per cent of the most important exhibited media art works.

${ }^{\mathrm{xxi}}$ DOCAM is a multidisciplinary research endeavour initiated by the Daniel Langlois Foundation in collaboration with numerous national and international partners, who wrote letters of support such as the Database of Virtual Art, and is funded by the Social Sciences and Humanities Research Council of Canada, http://www.docam.ca/ 